\title{
TROM A MULTI-ETHNIC EMPIRE TO A NATIONAL STATE: THE 1 CONTRIBUTION OF ROMANIAN OFFICERS IN THE HABSBURG ARMY TO THE CREATION OF GREATER ROMANIA AS PRESENTED BY TRANSYLVANIAN JOURNALISTS
}

\section{Mihaela Mehedinți-Beiean}

Babeș-Bolyai University, Cluj-Napoca, Romania, E-mail:

mihaela_mehedinti@yahoo.com

\section{Acknowledgements}

This work was supported by UEFISCDI through grant PN-III-P1-1.1-TE-2016-0432 entitled "Romanian Officers in the Habsburg Army and their Involvement in Civil Society (late 18th Century to 1918)", Project leader: Vlad Popovici.

This paper has been presented at the Ninth Annual International Conference on Baltic and Nordic Studies in Romania: 100 Years since Modern Independence and Unification in Baltic Sea Region and East-Central Europe held in Târgoviște, Romania, during November 15-16, 2018.

\footnotetext{
Abstract:

Greater Romania was created at the end of World War I as a result of both top-down and bottom-up processes that involved all social layers from Transylvania and the Old Kingdom. The present study focuses on a particular category of actors that took part in the Great Union of 1 December 1918, namely Romanian officers from the Austrian army, and on a specific set of sources, i.e. Transylvanian periodicals issued around this date. In order to answer a number of research questions centered on Romanian officers' contribution to the historical act that took place in Alba Iulia, I used articles that appeared throughout 1918 in four Transylvanian periodicals, namely Biserica și Scoala, Drapelul, Transilvania and Unirea. The study's chief aim is to provide a clear picture of the manner in which Romanian officers from the Austrian army were depicted by the press shortly before and after Transylvania's union with Romania was proclaimed, as well as of the nature of their participation
} 
in the events: as delegates of the National Guards or as agents whose goal was to ensure order during the meeting.

\section{Rezumat:}

România Mare a fost fondată la sfârșitul Primului Război Mondial ca urmare a proceselor derulate de la de la vârf spre bază (top-down) și de la bază spre vârf (bottom-up) care au implicat toate straturile sociale din Transilvania și din Vechiul Regat. Prezentul studiu se concentrează asupra unei anumite categorii de actanți care au luat parte la Marea Unire din 1 decembrie 1918, și anume ofițerii români din armata austriacă, și se bazează pe un tip bine definit de surse, periodice transilvănene emise în jurul acestei date. Pentru a răspunde la o serie de întrebări de cercetare referitoare la contribuția ofițerilor români la actul istoric care a avut loc la Alba Iulia am folosit articole care au apărut în 1918 în patru periodice transilvănene: "Biserica și Școala", "Drapelul”, "Transilvania” și "Unirea”. Scopul principal al studiului este de a oferi o imagine clară a modului în care ofițerii români din armata austriacă au fost reprezentați în presă în prezilele și în zilele de după unirea Transilvaniei cu România, precum și a naturii participării lor la evenimente: ca delegați ai Gărzilor Naționale sau ca agenți al căror scop era să asigure ordinea în timpul adunării.

Keywords: Romanian officers; Greater Romania; Austro-Hungarian Empire; Transylvanian periodicals; World War I

Romania's national day was not randomly picked, as the Great Union that was achieved on 1 December one hundred years ago undoubtedly represents the most important event in Romanians' history. The union of all provinces inhabited by a Romanian majority within the borders of a single national state could not have been possible in the absence of certain key factors, such as the dissolution of large empires at the end of World War I, an ever stronger nationalist ideology discernible all over Europe and an extremely favorable twist of fate that occurred towards the end of 1918.

It is common knowledge that Romania entered World War I with the hope of obtaining Transylvania, a desire widespread in all political circles and throughout Romanian society. Fortunately, this aim was achieved, although with tremendous sacrifices.

Transylvanians as well gravitated towards Romania, particularly after Emperor Franz Josef I died and Romania entered the war in 1916. Already strongly affected by their participation in the war and with a 
confused sense of loyalty, Romanians serving in the Habsburgs' army represent a very interesting category from the viewpoint of their involvement in the events that marked the last two years of the conflagration. Understandably, not all of their actions reached the general public, but, as the following pages will reveal, Romanian officers from the Austro-Hungarian army were relatively visible and Transylvanian periodicals issued in 1918 mentioned them in several contexts, the most important of these being the recognition of merits attained on the battlefield, their charitable and/or cultural activity and particularly the role they played in the events that unfolded towards the end of the year.

\section{Recognition of military merits}

Bravery deeds of Romanian officers from the Habsburg army were frequently mentioned by Romanian periodicals issued in Transylvania in 1918. Relevant articles habitually included a number of elements, such as the name of the officer who was decorated, the decoration(s) he received, the reasons which motivated this distinction and/or other relevant details: whom granted the decoration, if the officer was also advanced alongside being decorated, if he was decorated post-mortem, the context in which the decoration was received, etc. Interestingly enough, such information is also commonly found within the pages of religious publications, the most obvious reason for this being the fact that such articles had the potential to boost loyalty towards the Habsburgs' dynasty and to demonstrate that the sacrifices Transylvanian Romanians made were not in vain.

The most frequently mentioned orders granted to Romanians for deeds of bravery were the Military Order of Maria Theresa, the Empire's highest military honor, the Austrian Imperial Order of the Iron Crown, the Military Merit Cross, the Military Merit Medal or Signum Laudis, as it was also known, and the Medal for Bravery.

Examples of this recognition of military merits include such cases as the one of "Major Constantin Popoviciu, who also served at Regiment 33 from Arad, [who] was advanced as a reward for his bravery to the rank of vice-colonel and distinguished with the Austrian Imperial Order of Leopold. In the last fights from the Italian front he accomplished an extraordinary act of bravery right in front of the king, for which he was promoted to earn from the highest places the highest military decoration: the Order of Maria 
Theresa"1. Another recipient of the highest insignia was "Mr. Ioan Boieriu, retired Imperial and Royal General, also well-known within Romanian circles from Arad since the times he served Reg.[iment] 33, [who] obtained [the Military Order of Maria Theresa] for the extraordinary service done for the throne and motherland on the honor field"2.

Another highly decorated Romanian officer was Lieutenant Brutus Păcurariu, pertaining to the same Regiment 33 of Arad, who received four insignia, including the Austrian Imperial Order of the Iron Crown Class III and the Medal for Bravery Class I. Noteworthy, in civil life Brutus Păcurariu was a functionary of the "Victoria" Bank from $\mathrm{Arad}^{3}$. In a similar vein, Captain Victor Muntean, chief accountant of the "Patria" Bank from Blaj, "was decorated for the second time with Signum Laudis with the insignia of the swords, for his brave behavior and for eminent services rendered in front of the enemy" 4 .

Some press articles gave the impression that Romanian officers were fearless, as the next example demonstrates. Within a time frame of twelve months, Petru Florea, conscripted as sergeant, was promoted three times, attaining the rank of Offizier Stellvertreter, and decorated on five different occasions, receiving the Carol Cross, the Bronze Decoration twice, the Silver Medal Class I and the Silver Medal Class II ${ }^{5}$.

Particular cases were those of reservists, who could also be decorated, as was, for example, Lieutenant Dr. Virgil Besan, a lawyer from Lugoj, who received the Signum Laudis 6 , and of prisoners of war, a situation in which the decorations granted to them were sometimes sent to their families. This happened to infantry Lieutenant Dr. Iulius Ionescu who had bravely served on the battlefields of Serbia, Montenegro, Italy and France, receiving seven decorations, namely the Red Cross Medal for Humanity, the Bravery Medal, the Bronze Signum Laudis Medal, the Silver Signum Laudis Medal, the Carol

\footnotetext{
1 Biserica și Școala, No. 2, 7/20 January 1918, p. 2, article entitled “The Order of Maria Theresa for a Romanian".

2 Biserica și Școala, No. 33, 12/25 August 1918, p. 2, "Information" rubric, article entitled "A knight of the Order of Maria Theresa".

${ }^{3}$ Biserica și Școala, No. 9, 25 February/10 March 1918, p. 3, “Information" rubric, article entitled "Decorated Romanian officers".

4 Unirea, No. 33, 30 May 1918, p. 4, “Information" rubric, article entitled “Decoration”, original emphasis.

5 Drapelul, No. 41, 14/27 April 1918, p. 3, "Information" rubric, article entitled "Decorated".

6 Drapelul, No. 43, 21 April/4 May 1918, p. 3, "Information" rubric, article entitled "Decorated".
} 
Cross, the Military Merit Cross Class III with swords and the Iron Cross Class III with swords?

It seems that each periodical was interested in promoting local officers, such information probably best serving their readers' interests. Consequently, Drapelul wrote about Captain Alexandru Micu from Lugoj who had been repeatedly decorated for acts of bravery with the Military Merit Cross, the Carol Cross, the Imperial Austrian Franz Joseph Order and even with foreign decorations, such as the Bulgarian Grand Cross with crown8.

Other officers stood out not through the number of decorations received, but through their charitable actions. For instance, Captain Gheorghe Ivașcu, commander of the artillery station of Arad, was not only decorated with the Austrian Imperial Order of the Iron Crown Class III for his military merits, but he also received "a high and rare distinction" from his fellow townsmen due to his "social and humanitarian feelings" which motivated him to provide heating material to the destitute and as a result "his name is pronounced with veneration in the hut of the poor and with respect in the palace of the rich" 9 .

Habitually, information provided by the press about officers who had lost their lives on the battlefield was detailed and the ones in question were referred to as "heroes". One such "hero" was Benedict Ciotlos, Sublieutenant in infantry Regiment 50, who had been decorated for his courage, but who unfortunately lost his life in the "horrible attacks of Monte San Gabriele" after 20 months on the Italian front ${ }^{10}$. Imperial and Royal Sublieutenant Virgil Lazlo was decorated with the Military Merit Cross and Signum Laudis for his bravery act, but died at age 21, after nine months of suffering, because of the wounds he had received ${ }^{11}$.

Another officer deeply regretted by Transylvanian journalists was Simion Lateș, Captain of infantry Regiment 62, who died suddenly "as a towering oak struck by lightning". During his military career he had

\footnotetext{
7 Drapelul, No. 44, 26 April/9 May 1918, p. 3, "Information" rubric, article entitled "Decorated".

8 Drapelul, No. 25, 8/16 March 1918, p. 3, "Information" rubric, article entitled "Decorated".

9 Biserica și Școala, No. 9, 25 February/10 March 1918, p. 3, "Information" rubric, article entitled "Decorated Romanian officers".

10 Unirea, No. 10, 9 February 1918, p. 3, "Information" rubric, article entitled "Hero Benedict Ciotloş".

11 Unirea, No. 36-37, 19 June 1918, p. 8, article entitled “Obituary".
} 
repeatedly distinguished himself and his chest bearing the Iron Crown and eight other decorations proved this statement. Moreover, "His Majesty the King shook his hand on many occasions, as the highest sign of appreciation for his bravery". And as if this was not enough praise for this Romanian hero, the author of his obituary stressed the fact that he was a "true Christian", a "veritable apostle amidst the Romanian soldiers and people"12.

\section{Charitable and humanitarian acts, cultural merits, moral qualities revealed on the battlefield}

Apart from the examples of high moral qualities provided above, Transylvanian journalists mentioned Romanian officers from the Habsburgs' Empire in other instances as well, particularly when it came to their contribution to various charitable actions. As a result, we now know that officers Eugen Balint, Vasile Dobre, Victor Grama, Alexandru Kerülö, Ioan Maier and Dr. Octavian Deac, Sublieutenant and physician of the $12^{\text {th }}$ Honvéd Regiment, each donated 10 Korona to the fund for the GreekCatholic Romanian Orphanage ${ }^{13}$. Concerts and theatrical performances were also good opportunities for various associations and organizations to raise funds for humanitarian purposes and officers usually donated money on these occasions, according to their rank and particularly when they wanted to mark certain events, such as being promoted or decorated. It seems that the sums they gave to charity usually varied between 3 and 10 Korona, but it is interesting to note that military physicians were in the habit of renouncing to larger sums, which sometimes even went as high as 20 or 25 Korona ${ }^{14}$.

Buying felicitation cards was another manner in which money could be donated to various ends and, for example, Captain Romulus Boldea thus offered 14 Korona for the Romanian Journalists Fund ${ }^{15}$. The same fund also received 40 Korona as a donation made in the memory of a deceased grandfather by Captain Romulus Popa ${ }^{16}$. Perhaps in order to serve as an

\footnotetext{
12 Unirea, No. 36-37, 19 June 1918, p. 7, “Information" rubric, article entitled “† Captain Simion Lateș".

13 Unirea, No. 4, 19 January 1918, p. 4, "Information" rubric.

14 Unirea, No. 7, 31 January 1918, p. 4, No. 19, 23 March 1918, p. 3 and No. 33, 30 March 1918, p. 4, "Information" rubric, articles entitled "Public acknowledgement"; Unirea, No. 36-37, 19 June 1918, p. 7, "Information" rubric, article entitled "Subscriptions".

15 Drapelul, No. 7, 18/31 January 1918, p. 3, "Gifts and redemptions".

16 Drapelul, No. 42, 17/30 April 1918, p. 3, "Information" rubric, article entitled “Donations".
} 
example, such donations benefiting journalists and newspapers were made public and therefore contemporary readers also found out about the "Drapelul" fund and about the fact that Lieutenant M. Grosu had donated 8 Korona to it at the beginning of 191817 .

The sums were usually larger when it came to donations to cultural associations and in this respect the "Association for Romanian literature and the culture of the Romanian people", or ASTRA as it was called in short, probably holds the record. Retired officers afforded to give away relatively large sums of money for the advancement of Romanian culture, as the donation of 200 Korona from Imperial and Royal Captain Pantaleon Lucuța from Sibiu and that of 100 Korona made by Imperial and Royal General Alexandru Lupu reveal ${ }^{18}$.

In fact, Romanian officers' involvement in the Transylvanian cultural movement took on multiple forms, as proven by the fact that at the end of 1918, ASTRA counted amongst its founding and lifelong members nineteen officers and, interestingly enough, two wives of officers, namely Chintoan Aurora, born Lado, a major's wife from Brașov, and Lupu Blanca, wife of a general living in Vienna ${ }^{19}$. It should be mentioned that some of these officers were retired and had ranks varying from captain to general, the most notorious of them being General Traian Moșoiu.

Aside from cultural endowments, some officers were also mentioned by journalists due to attributes that distinguished them as excellent commanders of their troops. One such figure repeatedly invoked by Transylvanian periodicals is the one of Colonel Victor Rusu, who apparently not only defied dangers through his bravery acts, but also motivated and inspired his subordinates to do the same. One suggestive anecdote in this respect is the one which refers to Colonel Rusu's incursion behind enemy lines, dressed in the traditional Russian costume, in order to retrieve an announcement through which a large sum was promised in gold to the one who could bring the then Sublieutenant Rusu, dead or alive, into the hands of the Russian troops. "Fortunately, this desire of the Russian command was not realized", the journalist remarked ${ }^{20}$.

\footnotetext{
17 Drapelul, No. 19, 17 February/2 March 1918, p. 3, "Information" rubric, article entitled "Donation".

18 Drapelul, No. 36, 3/16 April 1918, p. 1, "Contributions to the 'Association'".

19 Transilvania, 1 December 1918, No. 1-12, pp. 3-31, "The official part" rubric.

20 Biserica și Școala, No. 36, 2/15 September 1918, p. 4, "Information" rubric, article entitled

"Colonel Victor Rusu".
} 
This almost supernatural story is completed by another article in which Colonel Victor Rusu was considered an "educator" of the soldiers he commanded, who worshipped him. One revealing incident in this regard is recounted by schoolteacher L. Cioban and it refers to one particularly devastating Russian offensive from 1916 ${ }^{21}$. On this occasion, one badly injured twice decorated Romanian foot soldier "was crying like a baby", although he was over 40 years of age. When asked why he was crying so hard he revealed that he did not want to leave Colonel Rusu's side, although this meant that he could see his wife and children for the first time after almost two years. He was crying because "for 21 months I was continuously with the Major... I was everywhere with him, in Serbia and in the Carpathians as well... for 21 months we were together!". The author of the article pondered upon this event and concluded that "Without knowing the personality of the legendary Rusu and all his charm, all the decisive force in the education received by the infantryman in the 21 months campaign, it is in fact difficult to understand his torment and crying". And, actually, all the major achievements of the redoubtable "Rusu detachment" were due to "the incomparable inventive art [through which] he knew how to enkindle aspirations into the heart of the troops". His moral consistency was "inexpugnable as a granite rock" and acted as "the driving force in the empire of common aspirations, which kept all of them in a tight cluster, so that none of them deviated to choose another path". Only after being thus educated in "the absolutely moral school of the aspirations guided by the originality of strategic talent and moral force of the able Rusu" were such soldiers capable of achieving incredible successes for the Austro-Hungarian army. And, even more important, such people were to return home open to multiple types of reform and keen to implement them, this element demonstrating why "the remarkable figure of Major Rusu stands as a model, as an edifying example", as one of the most powerful educators of the commoners.

\section{The role of Romanian officers from the Austro-Hungarian army in the events of 1 December 1918}

Romanian officers from the Habsburgs' army were involved in the Great Union in multiple manners, the most conspicuous of these being (a)

\footnotetext{
${ }^{21}$ Biserica și Școala, No. 41, 7/20 October 1918, pp. 3-4, article entitled “Colonel Victor Rusu as an educator" signed by L. Cioban, schoolteacher.
} 
the organization of Military Councils and various actions that preceded the events, (b) their participation as delegates of the National Guards to the Great National Assembly, (c) the role they played in the unfoldment of the events of 1 December 1918 per se, and (d) the functions they fulfilled shortly after Transylvania's union with Romania was proclaimed.

Ever since the planning of the National Assembly began, people were informed about the participation of Romanian officers and soldiers in the events, as the manifesto “To the Romanian nation!" signed by the National Romanian Council demonstrated. In this important document of the Great Union it was mentioned that "Each Romanian soldier, untied of the vow given to the emperor, is allowed to enter the national Romanian military council (Romanian national guard), to bear the proud symbol of his national sovereignty, the tricolor[,] and he should exclusively obey the Romanian national council"22. Moreover, "Romanian brothers" were announced that "Soon, brave soldiers and officers of the Romanian national guard will appear amongst you. Join them and use your Romanian arms and hearts to help and support them". In the meantime, the manifesto also noted that "Each Romanian officer and soldier who still has not announced himself and was not dispatched, has the duty to report without delay to the office of the Romanian National Council" 23 .

Fortunately, the fulfillment of this duty was supported by the Hungarian authorities, as the following message stemming from Albert Bartha, the Hungarian minister of defense, demonstrated: "I hereby announce Romanian officers, sub-officers and soldiers from Transylvania and Hungary that they can take a vow of loyalty towards the Romanian National Council. Their wage, their pay will be paid exactly as it is being paid to the ones who have sworn [loyalty] to the Hungarian National Council"24.

The appeal of the Romanian National Council was readily put into practice in all of Transylvania's administrative-territorial units, as proven by the large number of press articles giving details about the organization of the Romanian national guards. In these announcements, today's researchers discover names, ranks, minor events and attitudes that shaped the days prior

\footnotetext{
22 Biserica și Școala, No. 44, 28 October/10 November 1918, pp. 1-2, “To the Romanian nation!”, signed "For the Romanian National Council: Dr. Ștefan C. Pop".

23 Original emphasis.

24 Unirea, Propaganda No. 7, 20 November 1918, p. 1, "Notification".
} 
to the Great Union. One such example is the national military council of Timișoara, whose leaders were Lieutenant-Colonel S. Brândușa, Captain Dr. Ioan Popovici, Captain S. Borbaș, Captain Dr. Lucian Gheorghevici, Lieutenant Dr. Gheorghe Avram and Lieutenant Vasilie Eremiaș. And the readers of Biserica și Școala were also informed that, even before this council had been constituted, the vast majority of Romanian officers from Timișoara had declared "that their attitude will be entirely in conformity with the decisions that will be taken by the Romanian National Council, to which they adhere with resolute faith" 25 .

Similar messages were sent in Cluj as well, where citizens were informed that "The Council of the Romanian people and its legion from Cluj, all Romanian officers and soldiers, are working day and night so that the Romanian nation's peace and rights can become an accomplished fact!"26, this occurring under the command of Captain Poruț.

In Sibiu, the military council was headed by Major V. Liuba and "the Czech troops surrendered weapons, ammunition, automobiles and an airplane to the Romanians!" 27.

In Blaj, the events surrounding the constitution of the Romanian National Council and of the Romanian national guard were evoked in detail. The moment in which the gendarmerie was peacefully disarmed because it refused to join the Romanian national guard commanded by Captain Ioan Muntean and to wear the tricolor is proudly evoked by Unirea. Captain Muntean thus became one of the striking figures of the organization of the national guards, one journalist considering that whoever saw him during these events will never forget him, as "In Blaj he thawed out the hearts and started the avalanche!". Consequently, "Around 10 o'clock, with the melody and rhythm of the anthem 'To arms', the first national guard of Blaj came from the direction of the long street, on the street of the printing press, bringing in triumph the weapons of the gendarmerie that were surrendered willingly. Leading them was Captain Muntean, after him the theologians, with the riffles on their backs, a few students and other young men and some soldiers,

\footnotetext{
25 Biserica și Școala, No. 44, 28 October/10 November 1918, p. 4, “Information” rubric, article entitled "Romanian national military council in Timișoara".

26 Unirea, No. 69, 9 November 1918, p. 1, "The appeal of the National Council from Cluj", signed by the "Trustee of the Romanian National Council: Dr. Amos Frâncu, Commissioner of the people".

27 Unirea, Propaganda No. 3, 15 November 1918, pp. 1-2, "Historical moments".
} 
randomly encountered on the streets!"28. After the National Romanian Council was constituted, the bells of the Cathedral rang, "hundreds of chests sang the national anthem" and "Captain Muntean grabbed a tricolor flag, sat on the table and waved the flag over the heads of the gathering - as a national blessing. - Afterwards, a proud retreat of the guard, on the streets and to the 'stone of liberty'".

One interesting detail demonstrated by the text just quoted is that, at first, the guard was mostly composed of soldiers, clerics from the seminary and a few older pupils, but, with time and particularly after the arrival of Captain Virgil Pop, it became stronger as the officers and soldiers around Blaj also joined $i^{29}$. Captain Pop, accompanied by a newly equipped detachment of 25 men, had been sent by the Romanian National Council of Cluj in order to secure the railway stations ${ }^{30}$.

In Arad, the corps of Romanian officers swore allegiance to the Romanian national council, "took over a garrison, got equipped with the necessary weaponry and started preserving public order. Other Romanian officers were dispatched to all Transylvanian centers and to the centers of all areas inhabited by Romanians in order to form national and military councils everywhere" 31 .

Similar organizational actions were carried out in rural communities as well, where, after the national councils and guards were constituted, "the peace is complete, the order - exemplary. A lot of enthusiasm"32. Moreover, "the representatives sent from the center are received everywhere with goodwill and love. Passe-partout for all the Romanian communes is: the tricolor at the buttonhole. Without this sign, no one is entitled to be amidst our villages" 33 . It seems that these rural guards took their vows in the nearest towns and in some days Blaj hosted 10 to 15 such communal guards "who listened to the speeches of our men - delivered from some table in the courtyard of the gymnasium or from the Cathedral's balusters - and then

\footnotetext{
28 Unirea, Propaganda No. 3, 15 November 1918, pp. 1-2, "Historical moments", original emphases.

29 Unirea, No. 69, 9 November 1918, p. 1, "The national assembly of Blaj”.

30 Unirea, Propaganda No. 3, 15 November 1918, pp. 1-2, "Historical moments". Other details regarding the constitution of the military national guard in Blaj and the vows taken by rural military guards are available in Unirea, Propaganda No. 5, 17 November 1918, p. 1, “Historical moments".

31 Unirea, No. 69, 9 November 1918, pp. 2-3, "National organization".

32 Unirea, Propaganda No. 3, 15 November 1918, p. 2, "The organization of villages".

33 Unirea, Propaganda No. 3, 15 November 1918, pp. 1-2, "Historical moments".
} 
said, repeating after the duty officer, the words of the vow of the National Romanian Council. Messrs. Șt. R., Dr. C. O. H., Dr. Sz. have completely hoarsened. The guardsmen's enthusiasm and decidedness are beyond description" 34 .

Romanians from the (still) capital of the dying Habsburgs' Monarchy also mobilized at the end of October 1918 and so the Central Senate of Romanian officers and soldiers in Vienna came into being. Upon returning from the battlefield, Romanian military men from Vienna launched an appeal in which they emphasized that "The peoples of the AustroHungarian Empire are becoming organized on national and democratic bases. Consequently, the Romanian officers and soldiers from Bukovina, Transylvania and Hungary, in their gathering from today, held in Vienna, chose from amongst themselves a military Senate (council), as a military section of the Romanian national committee", its purpose being that of "organizing all Romanian officers and soldiers from these countries" 35 . The instructions given to military men illustrate the purposes that lay behind the conception of this organism and how it was supposed to function:

"1. Each Romanian soldier who is currently at the depots (the cadres) from the Monarchy or who returns from the front is the soldier of the Romanian national committee and will not accept any command from foreigners, nor will he take an oath for another foreign army or under another flag than that of the Romanians from Bukovina, Transylvania and Hungary.

2. Romanian soldiers will not let themselves be enticed for foreign purposes by other Romanian nations and will not join irregular groups led by particular interests that are hostile to the Romanian people.

3. Each Romanian soldier should keep away from abusive acts of robbery and plundering, because these crimes stand under the punishment of laws.

4. The Romanian soldier should not allow others to trample upon his national sentiments, but also he should not prevent the other cohabitant nations from the manifestation of their national will and from the exercise of national rights and he should not trample upon the national sentiments of others.

\footnotetext{
34 Unirea, Propaganda No. 5, 17 November 1918, p. 1, “Historical moments".

35 Unirea, No. 69, 9 November 1918, p. 2, "The Central Senate of Romanian officers and soldiers in Vienna".
} 
5. In each of the Empire's towns, where there are Romanian soldiers, a senate of Romanian officers and soldiers should be constituted - accepting these principles and following them to the letter. Each senate will send a delegate to the final central senate."

Towards the end of November, through the voice of its commander in chief, General Ioan Boieriu, the Central Senate announced local military senates that "in Vienna there are a number of high-ranking military men, former active officers and officers from the headquarters, whom with national liveliness place themselves at the disposal of local senates. At the same time, militia will also be sent where it is needed", in response to requests sent via telegraph to the Central Senate in Vienna ${ }^{36}$.

In fact, some of the most important and difficult tasks performed by the National Council with the help of the national guards were those of preserving order and of preventing pillaging. This was particularly hard to accomplish given that soldiers returned armed from the front. However, due to the fact that these two organisms coordinated their activity up to the point where members of the military national council participated at the works of the Romanian National Council, they managed to avoid major incidents caused by Romanians.

One interesting event, particularly given the manner in which it was tackled in the press, is the one labeled "The first deputation". A number of consecutive articles thus refer to the flight undertaken by aeroplane from Bacău to Blaj in 23 November 1918 in order to announce Transylvanians that "the Romanian army has crossed the Carpathians - through snow higher than two meters - and that they are coming to embrace us with brotherly love and to announce the foreign inhabitants of these lands as well that they come in the name of peace and of liberty for all peoples" ${ }^{37}$. Interestingly enough, although the pilot, Lieutenant Nicolescu (also spelled "Niculescu"), pertained to the Romanian army, Captain Precup, i.e. the copilot, was a Transylvanian. Both of them were described in detail and considered "Two characteristic heroes. Courageous sons of our people"38. Given that the aircraft (and its pilots) remained overnight in Blaj, "a guard of honor" commanded by Lieutenant Aurel Caliani was formed, a guard which

\footnotetext{
36 Unirea, Propaganda No. 7, 20 November 1918, p. 2, "Information" rubric, article entitled "Communiqué from the Central Senate of Romanian soldiers in Vienna".

37 Unirea, Propaganda No. 10, 24 November 1918, p. 2, "The first deputation".

38 Unirea, Propaganda No. 11-12, 27 November 1918, p. 3, "The arrival of the Romanian aeroplane / 23 November n.[ew style]".
} 
"watched over its refreshing sleep, keeping it safe from any unsettling event or unforeseen attack given current days' disorders".

As already mentioned, the participation of Romanian officers in the Great National Assembly took on several forms. The most obvious one was that they acted as delegates of the national guard, each county sending off one officer and one soldier to the assembly ${ }^{39}$. Another function they performed was related to the preservation of order, and, given that after 1 December 1918 the press provided details about how the Great National Assembly unfolded, one figure of a Romanian officer stands out, namely that of Lieutenant Ovid Grita, the one in charge of the Romanian national legion of Alba Iulia. The journalist only used words of praise in relation to Lieutenant Grita's actions during this historical event because "thanks to the admirable organization and to the enormous work done by Lieut. Grita as chief of police, not a single unpleasant incident disturbed and profaned the celebration's awe and greatness" 40 . Captain Medrea, commander in chief of the legion of honor from Alba Iulia during the Great Union, was also closely involved in the events' unfolding and his figure was also memorable for the gathering's participants. Together with Lieutenant Gritta, Captain Medrea received the ones who came by train to the assembly, namely LieutenantColonel Gagiu, commander of Regiment 5 Chasseurs "Mihai Viteazul", other officers of the Romanian army and "the guests from Blaj" 41.

Transylvanian journalists also registered the fact that in the same glorious day of 1 December 1918, King Ferdinand entered Bucharest accompanied by a Transylvanian detachment led by Lieutenant-Colonel Bordan. The moment's symbolism went even further, as the detachment used the tricolor flag given to it in Kishinev by Bessarabians in order to be flown in Alba Iulia ${ }^{42}$.

Even after the Great Union, national guards still played an important part in the preservation of order, as the following appeal demonstrates: "The commands of national guards, priests, schoolteachers and all intellectuals are provoked to provide detailed reports, if possible accompanied by

\footnotetext{
39 Unirea, Propaganda No. 11-12, 27 November 1918, p. 1, "Convocation”, signed by the "Great Council of the Romanian nation from Hungary and Transylvania".

40 Biserica și Școala, No. 48, 25 November/8 December 1918, pp. 1-2, "The Great National Assembly of Alba-Iulia".

41 Unirea, Propaganda No. 35-36, 27 December 1918, p. 2, article entitled "With the first Romanian troops at Alba Iulia", signed "Legionary Sandu".

42 Unirea, Propaganda No. 19-20, 7 December 1918, p. 6, “Information” rubric.
} 
documents and by the names of the witnesses, of all the atrocities that are being committed and were committed in their respective counties, mentioning the sacrifices, the names and the description of the circumstances. These reports are to be sent hurriedly, by courier, to the Romanian National Council from Arad for publication"43. Some incidents were in fact made public in the same number of Unirea in which this appeal was launched and they were signed by Sublieutenant Morariu. These reports concerned some inappropriate actions of Hungarian ethnics towards Romanians, namely some insults thrown by Hungarian gendarmes at a Romanian sergeant and the fact that a Hungarian patrol ripped out the Romanian tricolor off a peasant's chest, to which Sublieutenant Morariu ironically remarks: "Could it be that they took it for the colors' sake, so that they could have it as a memento?" 44 .

The return trips from Alba Iulia to the delegates' places of origin were sometimes accompanied by incidents, but, fortunately, these were usually not grave and/or were easily defused 45 . On the other hand, tragic events were not entirely uncommon and casualties sometimes occurred, as was the case in Agnita, where a Romanian captain was killed in an exchange of fire between Romanian officers and German soldiers ${ }^{46}$.

Order preservation measures and the involvement of military men in these operations continued for a while after 1 December 1918 and the press made it known: "Officers, aspirants for officers, military clerks and the aspirants for military clerks active in all branches, who have not already placed themselves at the disposal of the Romanian National Council, are provoked to present themselves in person the latest until 1 January 1919 new style to the chief of army and public safety in Sibiu. Those gentlemen who will not respond in a positive manner to this appeal - will not be taken into consideration. The headquarters of guards, legions, the chiefs of the Romanian bureaus need to immediately inform the chief of army and public

\footnotetext{
43 Unirea, Propaganda No. 21, 8 December 1918, p. 1, “Appeal”, signed by Ștefan C. Pop.

44 Unirea, Propaganda No. 21, 8 December 1918, p. 2, "Information" rubric, article entitled "Vexations".

45 One such example is available in Unirea, Propaganda No. 24, 12 December 1918, p. 2, article entitled "On the way to Bălgrad", signed by Ioan Sonea.

46 Unirea, Propaganda No. 26, 14 December 1918, p. 2, “The latest" rubric.
} 
safety about all the active officers, officer's clerks, aspirants for officers and aspirants for military clerks which are not indispensable to them" ${ }^{\prime 4}$.

Finally, the press also provided details regarding the manner in which the national military guards from Transylvania coordinated their activity with the Romanian headquarters shortly after the Great Union. For example, the Romanian army dispatched Sublieutenant in reserve Liciniu Simu in order to act as its connection with the battalion from Blaj ${ }^{48}$.

\section{Concluding remarks}

Fortunately, recent research has begun unraveling the numerous facets of the involvement of Romanians from the Habsburgs' army both in the conflagration and in the region's subsequent reshaping. Consequently, we are ever closer to understanding the metamorphoses of a socioprofessional category that not only began World War I serving one of the largest multi-ethnic empires and ended it as part of a new national state, but who also represented both a creator and a beneficiary of Romania's unification process.

Within this context, it is important to mention that Romanian officers of the Austro-Hungarian army were relatively often present in the pages of the epoch's Transylvanian periodicals. Information about them refers to the recognition of their military merits through decorations, to their charitable actions, to their involvement in the cultural life of the community or to their high moral qualities that recommended them as leaders of their troops. In this respect, some distinctive figures can be remarked, particularly those of Colonel Victor Rusu or Captain Ioan Muntean, but the press carefully informed its readers about Romanian officers from all territorial and administrative units.

Officers were involved in an extremely active manner both in the events that predated the Great Union and also during this historical event, as they participated not only as delegates, but also as agents for maintaining public order. Moreover, their stabilizing role was preserved after 1 December 1918 until this popular decision could be properly put into practice within the newly created Greater Romania.

\footnotetext{
47 Unirea, Propaganda No. 35-36, 27 December 1918, p. 3, "Provocation”, signed “Boeriu, m. p.".

48 Unirea, Propaganda No. 21, 8 December 1918, p. 2, "Information" rubric.
} 


\section{References:}

Biserica și Școala. Revistă bisericească, școlară, literară și economică [Church and School. A churchly, scholastic, literary and economic journal], 1918, Year XLII.

Drapelul. Organ național-politic [The Flag. A national-political organ], 1918, Year XVIII.

Transilvania. Revista Asociațiunii pentru literatura română și cultura poporului roman [Transylvania. The journal of the Association for Romanian literature and the culture of the Romanian people], 1918, Year XLIX.

Unirea. Foaie bisericească-politică [The Union. A churchly-political sheet] (subheading changed to Ziar național cotidian [Daily National Newspaper] during November and December), 1918, Year XXVIII. 